\title{
Correction to: Evidence-Based Practices for Children, Youth, and Young Adults with Autism: Third Generation
}

\author{
Kara Hume ${ }^{1,2}$ - Jessica R. Steinbrenner ${ }^{2} \cdot$ Samuel L. Odom ${ }^{2} \cdot$ Kristi L. Morin $^{2,3} \cdot$ Sallie W. Nowell ${ }^{2}$. \\ Brianne Tomaszewski ${ }^{2} \cdot$ Susan Szendrey ${ }^{4}$. Nancy S. Mclntyre ${ }^{2,5} \cdot$ Serife Yücesoy-Özkan ${ }^{2,6} \cdot$ Melissa N. Savage $^{2,7}$
}

Published online: 20 January 2022

(c) Springer Science+Business Media, LLC, part of Springer Nature 2022

\section{Correction to: \\ Journal of Autism and Developmental Disorders (2021) 51:4013-4032 https://doi.org/10.1007/s10803-020-04844-2}

Please note the following corrections to this article:

The article references Sensory Integration ${ }^{\circledR}$ (SI) four times in the text and in Table 2 and Fig. 4. To clarify the practice for which our review found evidence, these should instead read "Ayres Sensory Integration® (ASI®)". The corrected terminology can be found in all of our web-based materials: https://ncaep.fpg.unc.edu/research-resources
Publisher's Note Springer Nature remains neutral with regard to jurisdictional claims in published maps and institutional affiliations.
The original article can be found online at https://doi.org/10.1007/ s10803-020-04844-2.

\section{Kara Hume}

kara.hume@unc.edu

1 School of Education, The University of North Carolina at Chapel Hill, CB 3500 Peabody Hall, Chapel Hill, NC 27599, USA

2 Frank Porter Graham Child Development Institute, The University of North Carolina at Chapel Hill, Campus Box 8040, Chapel Hill, NC 27599-8040, USA

3 Present Address: College of Education, Lehigh University, Iacocca Hall, 111 Research Drive, Bethlehem, PA 18015, USA
4 Department of Allied Health Sciences, The University of North Carolina at Chapel Hill, Bondurant Hall, Campus Box 7120, Chapel Hill, NC 27599-7120, USA

5 Present Address: College of Health Professionals and Sciences, University of Central Florida, 12805 Pegasus Drive, Orlando, FL 32816, USA

6 Present Address: Department of Special Education, Anadolu Üniversitesi, Eğitim Fakültesi, Özel Eğitim Bölümü, Tepebaş1, Eskisehir 26470, Turkey

7 Present Address: College of Education, University of North Texas, 1300 W. Highland St., Denton, TX 76201, USA 